\title{
EFFECT OF CLEAR-CUTTING ON BRYOPHYTES IN PINE FORESTS OF THE SOUTH URALS
}

\section{ВЛИЯНИЕ СПЛОШНЫХ РУБОК НА МОХООБРАЗНЫЕ СОСНОВЫХ ЛЕСОВ ЮЖНОГО УРАЛА}

\author{
ELVIRA Z. BAISHEVA ${ }^{1}$, PAVEL S. SHIROKIKH ${ }^{1} \&$ VASILIJ B. MARTYNENKO ${ }^{1}$ \\ ЭЛЬВИРА 3. БАИШЕВАํ, ПАВЕЛ С. ШИРОКИХ ${ }^{1}$, ВАСИЛИЙ Б. МАРТЫНЕНКО ${ }^{1}$
}

Abstract

\begin{abstract}
In the Southern Urals, we investigated the process of natural forest regeneration and the changes in bryophyte component of the secondary plant communities originated after clear-cutting in the indigenous herbaceous-mossy pine forests. In study area, the clear-cutting facilitated the appearance of the long-term secondary pine-birch forests, which differ from natural pine forests by another tree species composition, greater herb cover and shading, low bryophyte cover. The bryophyte substrate groups respond to clear-cutting in different ways. The epixylic species are more labile and characterized by intensive processes of decreasing and increasing of diversity during the succession. The boreal forest floor species, e.g. Pleurozium schreberi and Hylocomium splendens clearly proved to be more resilient to the disturbances. The colonists (Ceratodon purpureus, Dicranella heteromalla, etc.) were particularly abundant during the period 5-10 years after cutting. In the secondary forests, the bryophyte richness was almost recovered in 40-60 years, but the abundance of some forest floor bryophytes declined significant. The bryophyte composition in the birch and pine forests slightly differs mostly due to elimination of few species that have low frequency in the forests before clear-cutting (Mnium spinosum, Lophozia ventricosa, etc.).
\end{abstract}

Резюме

Изучено изменение бриокомпонента в сукцессионных сообществах, возникших в процессе естественного лесовозобновления на месте рубки условно-коренных травяно-зеленомошных сосновых лесов Южного Урала. В районе исследования сплошные рубки способствуют возникновению длительно производных сосново-березовых лесов, которые отличаются от вырубленных сосновых лесов другим составом древостоя, более интенсивным затенением, высокой сомкнутостью травяного яруса, низким проективным покрытием напочвенных мхов. Субстратные группы мохообразных реагируют на вырубку по-разному. Эпиксильные мхи более лабильны и резко изменяют свое разнообразие в ходе восстановительной сукцессии. Среди бореальных напочвенных мхов Pleurozium schreberi и Hylocomium splendens оказались наиболее устойчивы к нарушениям. Виды-колонисты Ceratodon purpureus, Dicranella heteromalla и др. имели наиболее высокое обилие в течение 5-10 лет после рубки. Во вторичных лесах видовое богатство практически восстановилось за 40-60 лет, но обилие напочвенных мхов существенно сократилось. Флористический состав мохообразных березовых и сосновых лесов немного различается, в основном, за счет исчезновения видов, которые имели низкое постоянство в лесах до рубки (Mnium spinosum, Lophozia ventricosa и др.)

KEYWORDS: bryophytes, forest harvest, forest restoration, regenerative succession, pine forest, secondary birch forests, the South Urals.

\section{INTRODUCTION}

Bryophytes are important component of forest biodiversity (Rudolphi \& Gustafsson, 2011; Schmalholz \& Hylander, 2009; Jalonen \& Vanha-Majamaa, 2001, etc.), especially in the boreal forests. The forest vegetation covers $41.9 \%$ of the Bashkortostan territory (Gosudarstvennyi doklad..., 2013/ http://to02.rosreestr.ru/upload/to02/ files/нац_доклад_2013.pdf)). Natural forests of the region are represented by zonal temperate and coniferous forests and theirs mountain analogues.
In the region, intensive logging has been carried out for approximately 250 years. Currently, the areas of intact forests have been dramatically reduced being replaced with secondary communities. The natural forests have survived only in locations where access is difficult or in the protected areas (Martynenko, 2009). Fragmentation of forest habitat and change of tree stand composition might affect bryophytes by limiting dispersal possibilities and modification of microclimatic conditions. Many forest bryophytes are sensitive to high light intensities,

1 - Ufa Institute of Biology of Russian Academy of Sciences, October av., 69, Ufa, 450054 Russia - Россия 450054, г.Уфа, пр. Октября, д. 69, Уфимский институт биологии РАН; e-mails: elvbai@mail.ru, shirpa@mail.ru, vasmar@anrb.ru 


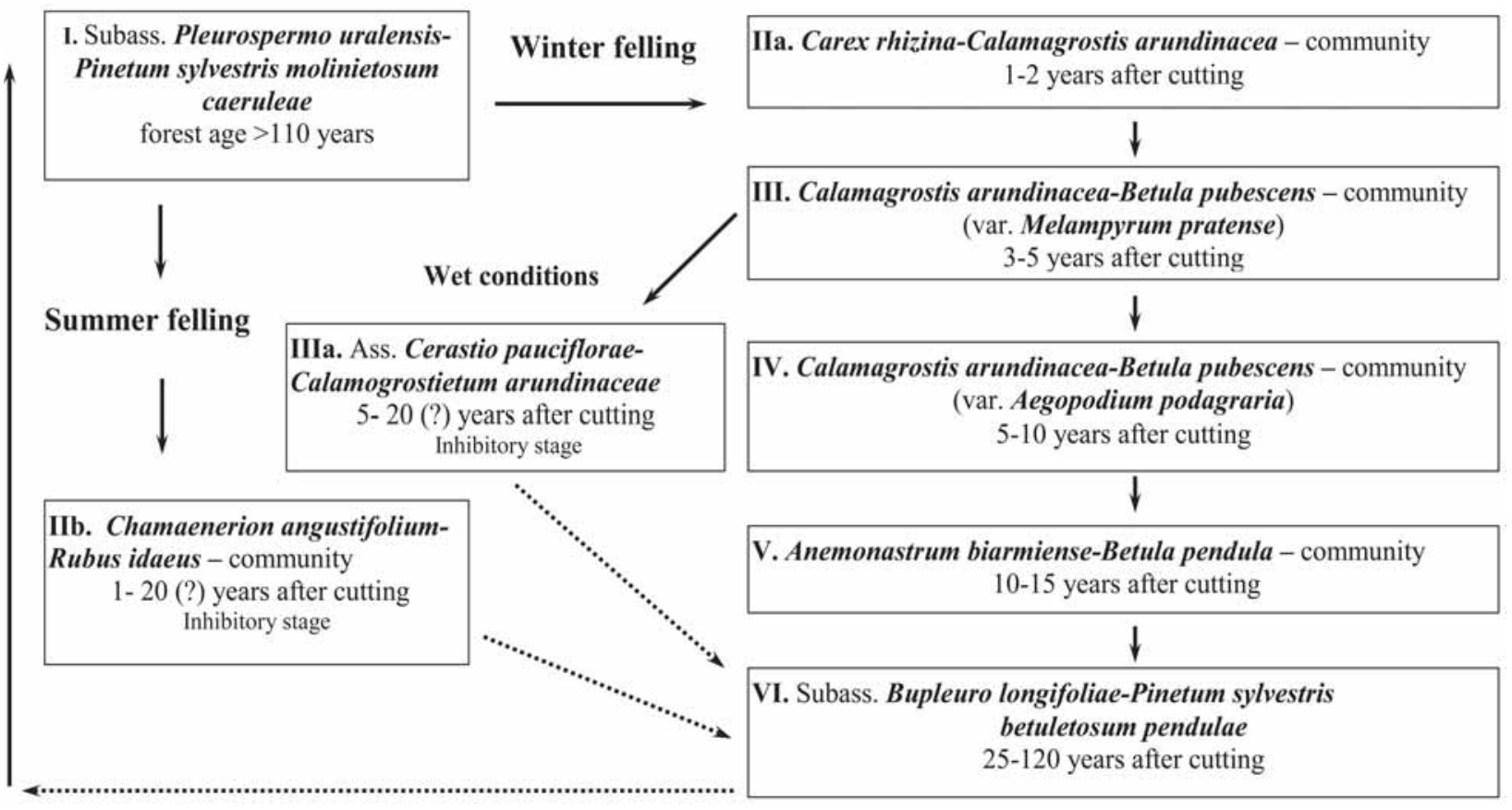

Fig.1. Scheme of regeneration succession after clear cutting of the inatural mountain grass-bilberry-moss pine forest (ass. Pleurospermo-Pinetum) in the study area

high temperatures, extensive droughts and fluctuating microclimates (Marschall \& Proctor, 2004). Natural regeneration after timber harvesting often leads to different tree species composition and may cause different understory biodiversity (Shirokikh et al., 2013; Ivanova, 2014; Yan et al., 2013, etc.); however, in the Southern Urals the effects of these processes on forest bryophytes are not well-known. Earlier, main subject of our investigations were bryophytes in different types of natural forests in the region (Baisheva, 2012, 2013; Baisheva \& Schirokikh, 2014, etc.). In this study, we examined changes in bryophyte diversity and composition in mountain grass-bilberry-moss pine forest and secondary plant communities originated from clear-cutting of this forest type.

\section{STUDY AREA AND METHODS}

The vegetation sampling was performed on 2011 in the Beloretskiy District of the Republic of Bashkortostan. According to natural zonation of the republic, the study area belongs to the district of light coniferous forests in the central area of the Southern Urals (Muldashev, 2010). It is located at $54^{\circ} 23^{\prime}-54^{\circ} 25^{\prime} \mathrm{N}$ and $58^{\circ} 42^{\prime}-58^{\circ} 44^{\prime} \mathrm{E}$. The relief consists of mountain ranges and depressions. The natural vegetation is presented by pine, larch and pine-birch forests. Currently, most of natural forests have been replaced by secondary birch, aspen and planted forests or meadows. The climate is moderately continental, with relatively warm summer and long cold winter. The mean temperature in January is $-16.0^{\circ} \mathrm{C}$, in July $+16.5^{\circ} \mathrm{C}$. The mean annual precipitation is $500-600 \mathrm{~mm}$. The frostfree period is 95 days (Yaparov, 2005).

Chronosequences are often used in succession studies, where a space-for-time substitution provides a pow- erful alternative to the time-consuming permanent plots (Foster \& Tilman, 2000). We selected sites with communities of various ages to make the geobotanical relevés as is necessary for detailed, floristic classification methods, after then these data were used to construct a dynamic range of communities (Aleksandrova, 1964). Restoration age dynamics from clear-cuttings (1-5 years old) up to tree stands of 60-120 years old has been studied (Fig.1). The period of time that has elapsed since clear-cutting have been estimated according to the data of forest management and using standard dendrochronological methods (Korchagin, 1960).

We have laid 78 sample plots with area $400 \mathrm{~m}^{2}$ (5-17 plots for each stage of regenerative succession). Much of sample plots were on gentle northern slopes up $3-5^{\circ}$ at 550-650 $\mathrm{m}$ above the sea level. These are the most common conditions for investigated forest type in the study area. In each plot, a list of all vascular plants and bryophytes was made, and the cover of each species growing on soil was evaluated according to Braun-Blanquet scale (Braun-Blanquet, 1964). For bryophytes, all substrates (tree trunks, dead wood, rocky substrate, etc.) were described.

Classification of vegetation was conducted according to the Braun-Blanquet approach using the TURBOVEG database (Hennekens \& Schamenée, 2001) and program JUICE (Tichy et al., 2011). The similarity of bryophyte composition in the communities included into the separate syntaxa has been estimated by the Jaccard index using program IBIS (Zverev, 2007).

Species names follow the list of vascular plants of the former USSR (Cherepanov, 1995), the check-list of moss 
Table 1 - Synoptic table of investigated communities (species with low constancy are not shown)

Community

Number of relevés

Time after logging, years

Cover of tree layer, \%

Cover of herb layer, $\%$

Cover of moss layer, \%

Number of bryophytes

Pinus sylvestris

Betula pubescens

Betula pendula

Larix sibirica

Betula pubescens

Betula pendula

Pinus sylvestris

Picea obovata

Abies sibirica

Vaccinium vitis-idaea

Vaccinium myrtillus

Lycopodium annotinum

Calamagrostis arundinacea

Rubus saxatilis

Carex rhizina

Brachypodium pinnatum

Melampyrum pratense

Molinia caerulea

Galium boreale

Chamaenerion angustifolium

Pleurozium schreberi

Hylocomium splendens

Dicranum scoparium

Ptilium crista-castrensis

Dicranum polysetum

Rhytidiadelphus triquetrus

Sciuro-hypnum curtum

Polytrichum juniperinum

Ceratodon purpureus

Atrichum undulatum

Dicranella heteromalla

Bryum caespiticium

Leptobryum pyriforme

Funaria hygrometrica

Pogonatum urnigerum

Pohlia andalusica

Trematodon ambiguus

Rhodobryum roseum

Dicranum fuscescens

Plagiomnium cuspidatum

Climacium dendroides

Dicranum bonjeanii

Mnium spinosum

Plagiomnium rostratum

Polytrichum commune

Dicranum montanum

Ptilidium pulcherrimum

Pohlia nutans

Stereodon pallescens

$\begin{array}{lllllllll}\text { I } & \text { IIa } & \text { III } & \text { IV } & \text { V } & \text { VI } & \text { IIIa } & \text { IIb } & \\ 9 & 10 & 8 & 8 & 14 & 17 & 8 & 5 & \\ >110 & 1-2 & 3-5 & 5-10 & 10-15 & 40-120(?) & 3-20(?) & 1-20(?) \\ 45 & 1 & 3 & 5 & 45 & 60 & 2 & 3 & \\ 45 & 40 & 55 & 70 & 55 & 70 & 80 & 90 & \\ 80 & 40 & 20 & 10 & 35 & 1 & 3 & 2 & \\ 40 & 29 & 13 & 22 & 34 & 37 & 33 & 14 & \end{array}$

$\begin{array}{llc}40 & 29 & 13 \\ & \text { Tree layer: }\end{array}$

$\begin{array}{lllllll}\mathrm{V}^{3} & \mathrm{I}^{\mathrm{r}} & \mathrm{II}^{+} & \mathrm{I}^{+} & \mathrm{II}^{+} & \mathrm{I}^{3} & \mathrm{I}^{\mathrm{r}} \\ \mathrm{IV}^{1} & \mathrm{I}^{\mathrm{r}} & \mathrm{I}^{+} & \mathrm{I}^{\mathrm{r}} & \mathrm{I}^{+} & \mathrm{V}^{+} & \mathrm{I}^{\mathrm{r}} \\ \mathrm{II}^{1} & \mathrm{I}^{\mathrm{r}} & \mathrm{I}^{\mathrm{r}} & \mathrm{I}^{\mathrm{r}} & \mathrm{II}^{1} & \mathrm{II}^{+} & . \\ \mathrm{II}^{1} & & & & \mathrm{II}^{+} & & \end{array}$

Undergrowth:

$\begin{array}{llllllll}\mathrm{IV}^{+} & \mathrm{II}^{\mathrm{r}} & \mathrm{V}^{+} & \mathrm{V}^{+} & \mathrm{III}^{1} & \mathrm{~V}^{+} & \mathrm{II}^{+} & \mathrm{I}^{\mathrm{r}}\end{array}$

$\begin{array}{llllllll}\mathrm{II}^{+} & \mathrm{III}^{\mathrm{r}} & \mathrm{IV}^{+} & \mathrm{V}^{+} & \mathrm{V}^{3} & \mathrm{I} & \mathrm{IV}^{+} & \text {. }\end{array}$

$\begin{array}{lllllll}\mathrm{V}^{\mathrm{r}} & \mathrm{I}^{\mathrm{r}} & \mathrm{II}^{\mathrm{r}} & \mathrm{V}^{1} & \mathrm{~V}^{1} & \mathrm{~V}^{\mathrm{r}} & \text { III }^{\mathrm{r}}\end{array}$

$\begin{array}{lllllll}\mathrm{V}^{+} & \mathrm{I}^{\mathrm{r}} & \mathrm{II}^{\mathrm{r}} & \mathrm{III}^{+} & \mathrm{III}^{\mathrm{r}} & \mathrm{III}^{\mathrm{r}} & \mathrm{II}^{\mathrm{r}}\end{array}$

$\mathrm{III}^{\mathrm{r}} \quad \mathrm{II}^{\mathrm{r}} . \mathrm{I}^{\mathrm{r}} \quad \mathrm{II}^{\mathrm{r}}$.

Herb layer:

$\begin{array}{lllllll}\mathrm{V}^{1} & \mathrm{IV}^{1} & \mathrm{~V}^{+} & \mathrm{V}^{+} & \mathrm{V}^{1} & \mathrm{II}^{+} & \mathrm{III}^{\mathrm{r}}\end{array}$

$\begin{array}{llll}\mathrm{V}^{2} & \mathrm{III}^{+} & \mathrm{V}^{+} & \mathrm{V}^{\mathrm{r}}\end{array}$

$\begin{array}{llll}\mathrm{IV}^{1} & \mathrm{IV}^{\mathrm{r}} & \mathrm{III}^{\mathrm{r}} & \mathrm{II}^{+}\end{array}$

$\begin{array}{llll}\mathrm{V}^{1} & \mathrm{~V}^{2} & \mathrm{~V}^{3} & \mathrm{~V}^{3}\end{array}$

$\begin{array}{llll}\mathrm{V}^{2} & \mathrm{~V}^{1} & \mathrm{~V}^{1} & \mathrm{~V}^{2}\end{array}$

$\begin{array}{llll}\mathrm{V}^{1} & \mathrm{~V}^{2} & \mathrm{~V}^{1} & \mathrm{~V}^{2}\end{array}$

$\begin{array}{llll}\mathrm{V}^{+} & \mathrm{I}^{\mathrm{r}} & \mathrm{V}^{+} & \mathrm{III}^{+}\end{array}$

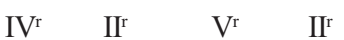

$\begin{array}{llll}\mathrm{IV}^{+} & \mathrm{II}^{\mathrm{r}} & \mathrm{IV}^{+} & \mathrm{V}^{1}\end{array}$

$\begin{array}{llll}\mathrm{V}^{+} & \mathrm{IV}^{+} & \mathrm{V}^{+} & \mathrm{V}^{+} \\ & \mathrm{II}^{+} & \mathrm{V}^{+} & \mathrm{V}^{+}\end{array}$

$\mathrm{V}^{+} \quad \mathrm{I}$

$\mathrm{II}^{1} \quad$ III $^{1} \quad$ III $^{\mathrm{r}}$

$\begin{array}{lll}\mathrm{V}^{2} & \mathrm{~V}^{2} & \mathrm{~V}^{2}\end{array}$

$\begin{array}{lll}\mathrm{V}^{1} & \mathrm{~V}^{1} & \mathrm{~V}^{1}\end{array}$

$\mathrm{V}^{1} \quad \mathrm{III}^{1}$

$\begin{array}{lll}\mathrm{V}^{2} & \mathrm{~V} & \mathrm{~V}^{+}\end{array}$

$\mathrm{I}^{\mathrm{r}}$

$\mathrm{III}^{\mathrm{r}}$

$\begin{array}{ll}\mathrm{III}^{+} & \mathrm{I}^{\mathrm{r}} \\ \mathrm{V}^{+} & \mathrm{V}^{+}\end{array}$

$\begin{array}{lll}\mathrm{V}^{+} & \mathrm{V}^{1} & \mathrm{IV}^{+}\end{array}$

Bryophytes mainly growing on the soil:

$\begin{array}{llllllll}\mathrm{V}^{4} & \mathrm{~V}^{3} & \mathrm{~V}^{2} & \mathrm{~V}^{2} & \mathrm{~V}^{3} & \mathrm{~V}^{+} & \mathrm{V}^{+} & \mathrm{III}^{+} \\ \mathrm{V}^{2} & \mathrm{IV}^{1} & \mathrm{~V}^{1} & \mathrm{~V}^{+} & \mathrm{IV}^{1} & \mathrm{III}^{+} & \mathrm{II}^{+} & \mathrm{I}^{+} \\ \mathrm{III}^{+} & \mathrm{I}^{+} & \mathrm{II}^{+} & \mathrm{II}^{+} & \mathrm{II}^{+} & \mathrm{III}^{+} & \mathrm{I}^{+} & \mathrm{I}^{+} \\ \mathrm{IV}^{1} & \mathrm{III}^{+} & \mathrm{IV}^{+} & \mathrm{III}^{+} & \mathrm{III}^{1} & \mathrm{III}^{+} & \cdot & . \\ \mathrm{II}^{\mathrm{r}} & \mathrm{I}^{\mathrm{r}} & \mathrm{II}^{+} & \mathrm{I}^{+} & \mathrm{I}^{+} & \mathrm{II}^{+} & \cdot & . \\ \mathrm{IV}^{+} & \mathrm{IV}^{+} & \cdot & . & \mathrm{II}^{+} & \mathrm{III}^{\mathrm{r}} & . & \mathrm{I}^{\mathrm{r}} \\ \mathrm{I}^{+} & \mathrm{I}^{+} & . & \mathrm{I}^{+} & \mathrm{II}^{+} & \mathrm{I}^{+} & \mathrm{III}^{+} & \mathrm{III}^{+}\end{array}$

$\begin{array}{llllllll}\mathrm{I}^{+} & \mathrm{I}^{+} & \cdot & \mathrm{I}^{+} & \mathrm{II}^{+} & \mathrm{I}^{+} & \mathrm{III}^{+} & \mathrm{III}^{+}\end{array}$

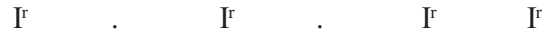

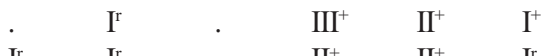

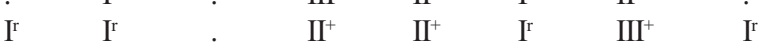

$\begin{array}{lll}\text { I } & \text { II } & \text { III }\end{array}$

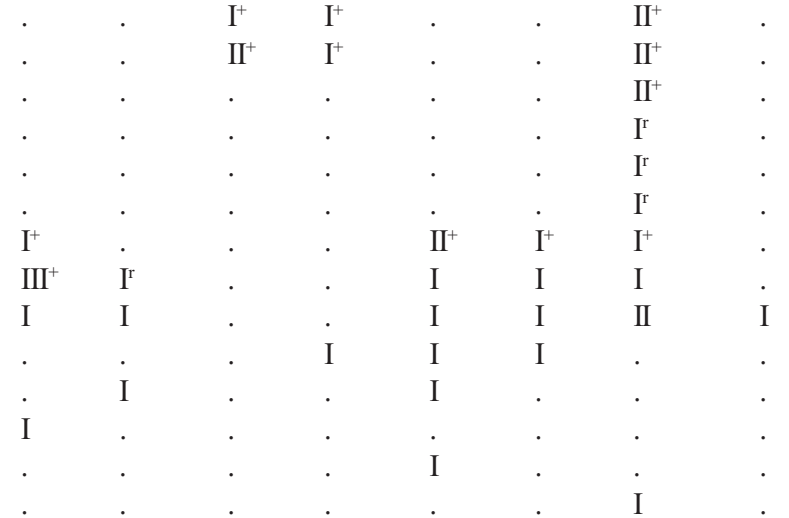

Bryophytes mainly growing on the rotten wood and bark of living trees:

$\begin{array}{llllllll}\text { IV } & \text { IV } & \text { I } & \text { III } & \text { IV } & \text { V } & \text { IV } & \text {. } \\ \text { IV } & \text { III } & \text { III } & \text { II } & \text { II } & \text { IV } & \text { II } & \text {. } \\ \text { I } & \text { I } & \text { I } & \text { II } & \text { II } & \text { II } & \text { IV } & \text { I } \\ \text { III } & \text { I } & \text {. } & \text {. } & \text { II } & \text { IV } & \text { II } & \text {. }\end{array}$


Table 1 (continied)

Species

Sciuro-hypnum reflexum

Amblystegium serpens

Brachythecium salebrosum

Lophocolea heterophylla

Callicladium haldanianum

Dicranum flagellare

Sanionia uncinata

Pylaisia polyantha

Platygyrium repens

Sciuro-hypnum starkei

Lophoziopsis longidens

Brachytheciastrum velutinum

Cephaloziella hampeana

Lophocolea minor

Plagiothecium laetum

Tetraphis pellucida

Plagiothecium denticulatum

Cynodontium strumiferum

Campylidium sommerfeltii

Pseudoleskeella nervosa

Lophozia ventricosa

Radula complanata

Frullania bolanderi

Paraleucobryum longifolium

Eurhynchiastrum pulchellum

Hedwigia ciliata

\begin{tabular}{|c|c|c|c|c|c|c|}
\hline I & IIa & III & IV & $\mathrm{V}$ & VI & IIIa \\
\hline I & I & . & . & I & I & II \\
\hline I & II & . & II & II & I & IV \\
\hline I & II & . & II & IV & I & IV \\
\hline II & I & . & II & II & II & IV \\
\hline II & I & . & I & II & III & II \\
\hline II & I & . & II & I & II & II \\
\hline II & II & I & . & II & III & II \\
\hline I & I & . & I & I & I & . \\
\hline & . & . & . & I & III & I \\
\hline I & I & . & . & . & . & I \\
\hline I & . & . & . & . & I & I \\
\hline 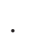 & . & . & . & I & . & I \\
\hline I & . & . & I & I & . & . \\
\hline I & I & . & . & I & . & . \\
\hline I & I & . & . & . & I & . \\
\hline I & . & . & . & I & I & . \\
\hline I & & & & & . & \\
\hline I & . & I & . & . & I & . \\
\hline II & I & . & . & . & I & . \\
\hline I & . & . & . & . & I & . \\
\hline I & . & . & . & . & . & . \\
\hline I & . & . & . & . & I & . \\
\hline
\end{tabular}

Bryophytes mainly growing on rock outcrops:

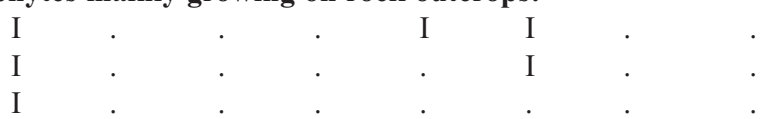

Communities: I - subass. Pleurospermo uralensis-Pinetum sylvestris molinietosum caeruleae; IIa - Carex rhizinaCalamagrostis arundinacea - community; III-IV - Calamagrostis arundinacea-Betula pubescens - community (III - var. Melampyrum pratense; IV - var. Aegopodium podagraria); V - Anemonastrum biarmiense-Betula pendula - community; VI subass. Bupleuro longifoliae-Pinetum sylvestris betuletosum pendulae; IIIa - ass. Cerastio pauciflorae-Calamogrostietum arundinaceae, IIb - Chamaenerion angustifolium-Rubus idaeus - community . The constancy of species have been evaluated according to the following scale: I - species is revealed in 1-20\% relevés of given syntaxa, II - 21-40\%, III - 41-60\%; IV - 61-80\%, $\mathrm{V}-81-100 \%$. For species growing on ground the abundance on the sample plots is given: $\mathrm{r}-$ extremely rare, +- cover not more than $1 \%, 1-1-5 \%, 2-5-25 \%, 3-25-50 \%, 4-50-75 \%, 5-75-100 \%$.

es of Eastern Europe and Northern Asia (Ignatov, Afonina, Ignatova et al., 2006) and the check-list of liverworts (Marchantiophyta) of Russia (Konstantinova, Bakalin et al., 2009).

\section{RESULTS}

Studies were performed in clear-cutting areas that earlier were covered by natural pine forests belonging to association Pleurospermo uralensis-Pinetum sylvestris Martynenko et al. 2003 (class Vaccinio-Piceetea Br.-Bl. in Br.-Bl., Sissingh et Vlieger 1939, alliance DicranoPinion (Libbert 1933) Matuszkiewicz 1962). Currently, these pine forests with complex understory vegetation comprising grasses, boreal dwarf shrubs and mosses occur in the mountain ridges Kraka and Ural-Tau as well as in the valleys of mountain rivers Belaya, Uzyan, Manyava, etc. (Martynenko, 2009). The communities are present on sandy mountain forest soils with normal moistening and often grow in contact with hemiboreal pine, larch and birch herbaceous forests included into the class Brachypodio pinnati-Betuletea pendulae Ermakov, Koroljuk et Latchinsky 1991.
The plant communities that relate to different stages of reforestation process are schematically shown in Fig. 1. The peculiarities of each community type structure are described below. The position of syntaxa in the floristic classification system according to the Braun-Blanquet approach is given in parentheses.

I. Subassociation Pleurospermo uralensis-Pinetum sylvestris molinietosum caeruleae Kunafin 2014 prov. (class Vaccinio-Piceetea) represents old-growth grassbilberry-moss pine forests with Betula pendula, B. pubescens and Larix sibirica. The age of older trees is 110 years and more. The herbaceous layer is characterized by predominance of Vaccinium myrtillus and Rubus saxatilis (Kunafin, 2014). In total, 40 bryophyte species were found on 9 sample plots (Table 1). Bryophyte cover varies from 10 to $95 \%$, an average for $80 \%$. Pleurozium schreberi and Hylocomium splendens are dominants, Dicranum scoparium, Rhytidiadelphus triquetrus and Ptilium crista-castrensis have high constancy. Dicranum montanum, Ptilidium pulcherrimum and Stereodon pallescens are common on the tree bases 


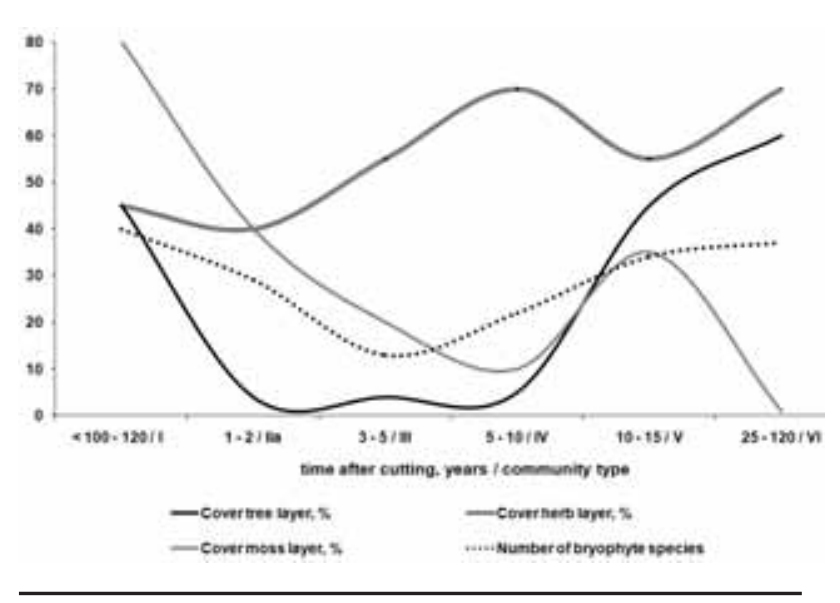

and decaying wood. Epilithic and epiphytic bryophytes are rarely encountered.

IIa. Carex rhizina-Calamagrostis arundinacea community (class Molinio-Arrhenatheretea Tx. 1937, order Carici macrourae-Crepidetalia sibiricae Ermakov et al. 1999) occurs in the felling area during 1-3 years following winter clear-cutting under which the ground cover is not very strongly damaged. Due to high illumination the abundance of boreal moss cover is drastically reduced (from $80 \%$ in intact forests to $40 \%$ in this community), in contrast to Calamagrostis arundinacea and Carex rhizina, that increase the coverage very fast (from 5 to $15-25 \%$ ) (Kunafin, 2014). Boreal herbs and mosses mostly exist in groups around stumps and bases of isolated seed trees which have been left untouched in order to provide the regeneration of target tree species.

III -IV. Calamagrostis arundinacea-Betula pubescens - community (class Molinio-Arrhenatheretea, order Carici macrourae-Crepidetalia sibiricae) is typical for the next stages of reforestation process. It is represented by 2 variants: Melampyrum pratense (3-5 years after clear-cutting) and Aegopodium podagraria (5-10 years after clear-cutting).

The meadow communities of var. Melampyrum pratense are characterized by thick (40-60\%) and high (20-80 $\mathrm{cm}$ ) herbaceous layer dominated by Calamagrostis arundinacea, Carex rhizina, Rubus saxatilis and appearance of large number of tree seedlings (Kunafin, 2014). Bryophyte composition is pure and much differs from primary forest type (table 2) due to the absence of some epixylic species.
Fig.2. Changes of forest layers cover and bryophyte richness in the different stages of regeneration succession

Bryophyte cover continues to reduce and is represented mostly by Pleurozium schreberi and Hylocomium splendens.

Communities of var. Aegopodium podagraria are characterized by active growth of birch, pine and rarely spruce undergrowth (height of young trees is 1-3 m), continuous decline of moss cover (to 10\%) and increase of sedges and graminoids cover (Calamagrostis arundinacea, Molinia caerulea, Carex rhizina, etc.). Boreal herbs are represented by a few plants, bryophytes grow mostly on decaying wood of stumps and felling waste.

V Anemonastrum biarmiense-Betula pendula-community (class Brachypodio-Betuletea, order Chamaecytiso ruthenici-Pinetalia sylvestris Solomeshch et Ermakov in Ermakov et al. 2000) appears in felled area $10-15$ years after clear-cutting. It is represented by young birch forests, rarely with codominance of Pinus sylvestris. The herbaceous layer is dominated by Brachypodium pinnatum, Calamagrostis arundinacea, Carex rhizina, Rubus saxatilis (Kunafin, 2014). In comparison with previous succession stage, herb cover is slightly reduced due to shading canopy of trees (cover is $35-50 \%$, height -3-6 m). It has a positive effect on development of bryophyte cover (25-60\%, an average for 35\%). In forest floor Pleurozium schreberi and Hylocomium splendens are the most abundant.

VI. The hemiboreal grass pine-birch forests of subassociation Bupleuro longifoliae-Pinetum sylvestris betuletosum pendulae Kunafin 2014 prov. (class Brachypodio-Betuletea, order Chamaecytiso ruthenici-Pinetalia sylvestris) occupies sites of 25-40 years after clearcutting. The herbaceous layer is dominated by Calamagrostis arundinacea, Rubus saxatilis, Carex rhizina. The herb cover may reach 55-70\%, suppressing the development of coniferous undergrowth and bryophytes (Kunafin, 2014). The cover of forest floor bryophytes is low (1\%), they grow on the bases of birch trunks and rotten wood. The richness and composition of epixylic bryophyte species is close to that typical for natural pine forests.

The process of regenerative succession is not strongly determined. In some cases, the succession can slow down due to the inhibitory effect from meadow communities with dense herbaceous cover (>80-90\%) which may hinder the

Table 2 - The Jaccard's similarity index (Ji) value for bryophytes composition in plant communities which represents different stages of regenerative succession

$\begin{array}{lllllllll} & \text { I } & \text { IIa } & \text { III } & \text { IV } & \text { V } & \text { VI } & \text { IIIa } & \text { IIb } \\ \text { I } & 1 & 0.6 & 0.26 & 0.38 & 0.61 & 0.75 & 0.43 & 0.32 \\ \text { IIa } & 0.6 & 1 & 0.27 & 0.55 & 0.66 & 0.61 & 0.51 & 0.48 \\ \text { III } & 0.260 .27 & 1 & 0.4 & 0.27 & 0.28 & 0.28 & 0.23 \\ \text { IV } & 0.380 .55 & 0.4 & 1 & 0.51 & 0.44 & 0.45 & 0.33 \\ \text { V } & 0.610 .66 & 0.27 & 0.51 & 1 & 0.69 & 0.52 & 0.33 \\ \text { VI } & 0.750 .61 & 0.28 & 0.44 & 0.69 & 1 & 0.49 & 0.34 \\ \text { IIIa } & 0.430 .51 & 0.28 & 0.45 & 0.52 & 0.49 & 1 & 0.34 \\ \text { IIb } & 0.320 .48 & 0.23 & 0.33 & 0.33 & 0.34 & 0.34 & 1\end{array}$




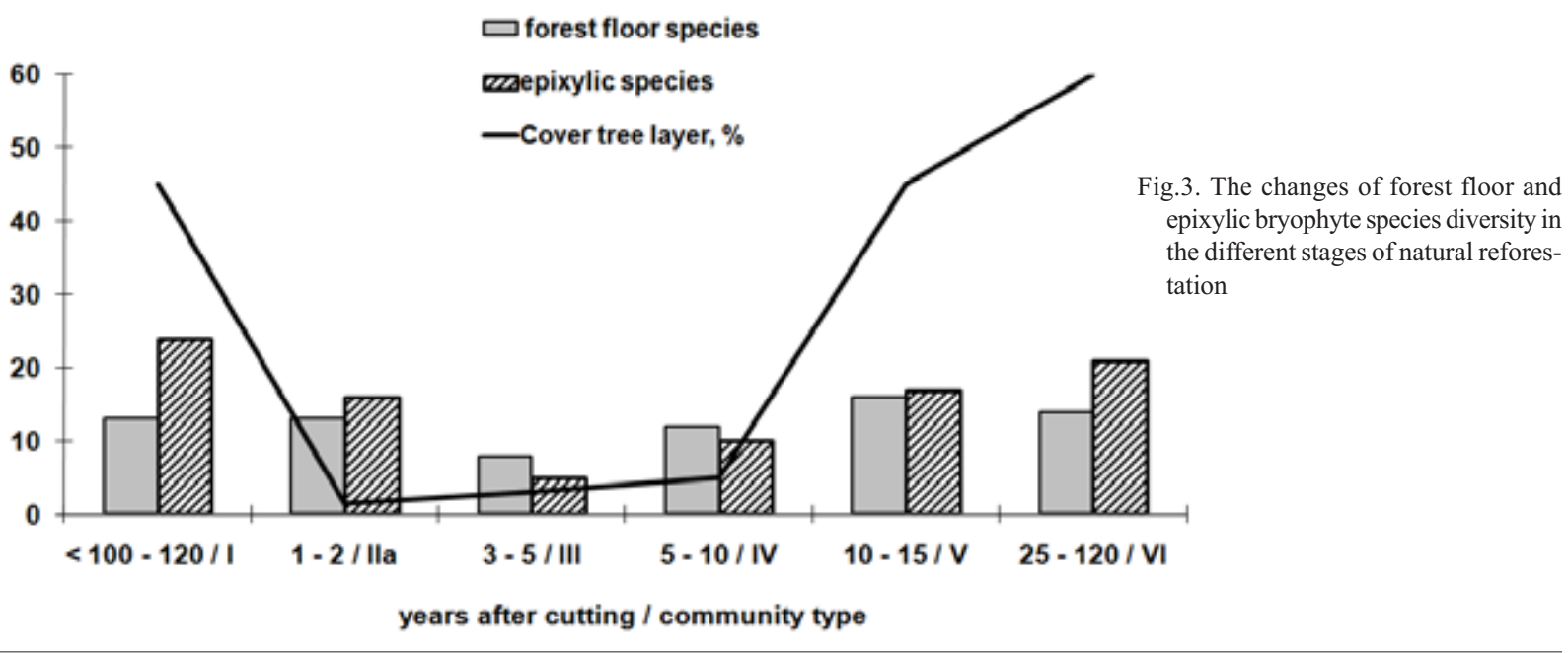

development of tree seedlings for many years. Two types of such communities are described below.

IIIa Association Cerastio pauciflorae-Calamogrostietum arundinaceae Kunafin 2014 prov. (class Molinio-Arrhenatheretea, order Carici macrourae-Crepidetalia sibiricae) units tall herb meadows that may occupy wet sites after 5-20 years following clear-cutting. As a rule, these communities are situated in the depressions with more mesophytic conditions and near the adjacent forest walls, where snow may be accumulated. Herbaceous layer combines tall herb, motley grass, grasses and sedges (Aegopodium podagraria, Calamagrostis arundinacea, Carex rhizina, etc.). Bryophytes have a small cover $(3 \%)$. The bryophyte composition is particularly heterogeneous and includes boreal species (Pleurozium schreberi, Hylocomium splendens, etc.), ruderal lightdemanded colonists (Dicranella heteromalla, Leptobryum pyriforme, Pohlia nutans, etc.) and epixylic species (Dicranum montanum, Brachythecium salebrosum, etc.), growing on rotten wood and bases of stumps.

IIb Chamaenerion angustifolium-Rubus idaeus community (class Epilobietea angustifolii Tüxen et Preising ex von Rochow 1951, alliance Fragarion vescae Tüxen ex von Rochow 1951) occupiesy disturbed sites that appear as a result of summer felling. In these relatively small areas $\left(15-30 \mathrm{~m}^{2}\right)$, the ground cover is almost completely destroyed and occurs in spots where felling waste have been stored and burned. The dense cover of dominant Chamaenerion angustifolium (about 180-220 $\mathrm{cm}$ high) and co-dominant Urtica dioica inhibits the restoration of forest for 20 and more years following clearcutting. Later the dominance of Chamaenerion angustifolium may be weakened due to shading of tree canopy of nearby young forest.

The changes of bryophyte diversity and covers of tree, herb and moss layers in the communities representing the different succession stages are shown in Fig.2 and Table 1. In comparison with natural pine forests, the total bryophyte diversity is reduced to $70 \%$ during 3-5 years after clear-cutting in the communities III and IIb. In the meadow communities with more mesophytic habitat conditions (community IIIa), the decline in bryophyte richness was not so sharp (to 10\%), despite the high level of shading by herbaceous layer, which is covered $80 \%$ of sample plots (Table 1). The lowest similarity with bryophyte composition of pine forest has been revealed 3-10 years after felling in the communities III (Jaccard index 0.26 ) and IV (Jaccard index 0.38), as well as in the inhibitory community IIb and IIIa (Table 2).

The total bryophyte diversity begins to increase in 510 years after clear-cutting (Fig. 2). In the community IIb dominated by Chamaenerion angustifolium, this process may be delayed for 20 years and more. The bryophyte richness in secondary birch forests (37 species) appearing 25 years after clear-cutting is close to analogical parameters in the natural pine forests (40 species), but the similarity of bryophyte composition in these communities is not high, the value of Jaccard index does not exceed 0.75 (table 2 ). The differences are mainly related to the absence of some species with low constancy (Mnium spinosum, Cephaloziella hampeana, Lophocolea minor, etc.).

In 1-5 years immediately following clear-cutting, the number of epixylic bryophytes declines to $75-80 \%$, but later it begins to increase quite fast (fig. 3) and in 25-30 years may consist approximately $90 \%$ of epixylic bryophytes composition of pine forest. The change of ground species richness is not so obvious. It declines to $40 \%$ in the community III and may reach the ground species richness of the natural pine forest in 10-15 years after clearcutting.

After 25-40 years of forest harvesting, the boreal mosses Pleurozium schreberi, Hylocomium splendens, Dicranum scoparium, etc. reduce their abundance, surviving mostly on the bases of trees and decaying wood. Ptilium crista-castrensis, Dicranum polysetum and Rhytidiadelphus triquetrus are almost absent in communities II b and IIIa, characterized by tall and thick herb cover $(80-90 \%)$. The constancy of boreal species does not or only slightly decrease in most successional com- 
munities (except II b and IIIa), these species are observed on the bases of trees and decaying wood.

The light demanded colonists (Ceratodon purpureus, Atrichum undulatum, Dicranella heteromalla, Bryum caespiticium, Leptobryum pyriforme, Funaria hygrometrica, etc.) are typical for disturbed sites (especially in community IIIa) and particularly abundant during the period 5-10 years after felling. The abundancy of these species is reduced in the community $\mathrm{V}$ (table 1 ) which is characterized by increasing of cover $(45 \%)$ and height (to 3-6 m) of trees.

In comparison with total bryophyte richness, the cover of forest floor mosses decreases slower and reduces by 85\% after 5-10 years after felling (fig.2). In the young birch forests $(\mathrm{V})$ the moss cover may slightly increase (to $35 \%$ ) simultaneously with some decreasing of herb cover. The minimum indicators of moss cover was revealed in the secondary birch forest (community VI) and in the inhibitory succession stage in communities IIb and IIIa (table 1) with thick herb cover (80-90\%).

\section{DISCUSSION}

According to genetic forest typology of B.P. Kolesnikov (1974), all forests (ecosystems) representing a certain stage of regeneration or age succession are included into one dynamic forest type unified by more stable parameters of certain forest area, or type of forest site (Ivanova \& Zolotova, 2014). Based on that approach, the study of changes in bryophyte component of successional communities that form a cycle in one particular type of forest site is of particular importance. It provides a method for evaluating of potential changes of bryophyte richness in a landscape unit taking into consideration the changes in surrounding vegetation. We studied the dynamic range of communities represented in one such type of forest site (the gentle northern slopes with sandy mountain forest soils in the central part of the Southern Urals).

In Bashkortostan, birch forests are an important vegetation type, covering more than $26 \%$ of forested area of the republic (Khairetdinov, 2004). Very often, these secondary forests are formed after clear-cutting of coniferous and deciduous forests. In most of places in the study area, the clear-cutting in the grass-moss pine forests facilitated the development of the long-term secondary pinebirch forests, which differ from natural forests by another tree species composition, greater herb cover and shading, low bryophyte cover, etc. The observations on the dynamics in the Urals secondary birch forests shows, that 40-60 year olds stands are characterized by maximum participation of birch, but in 80-100 years old forests the proportion of birch begins to decline due to the increased role of pine and larch (Andreyev, 2011). We succeeded in making a one relevé of a moss-bilberry birch forest aged 110 years that was almost identical in floristic composition to intact pine forest of the association Pleurospermo-Pinetum and contained vigorous pine undergrowth (sufficient for subsequent restoration of tree stand) under its canopy. Thus, the complete cycle of progressive succession should take more than 200 years (Shirokikh et al., 2013).

At the landscape level, the distribution of bryophytes is mainly determined by availability of suitable substrates and habitats (van Zanten \& Pocs, 1981; Rambo, 2001, etc.). Being less dependent from the surrounding vegetation, many bryophyte species occur in a wide range of associations (Korotkov, Morozova, 1989). We have tried to figure out how the bryophytes typical for of natural pine forests may survive for a long time in the different microhabitat conditions modified by surrounding successional vegetation.

It should be noted that bryophyte substrate groups respond to clear-cutting in different ways (the changes of epilitic species have not been analyzed due to their low frequency in the investigated communities). The epixylic species are more labile and characterized by intensive processes of decreasing and increasing of diversity during the succession. Probably, main factors reducing the epixylic species diversity are long period of high illumination and aeration (in the community III appeared on 3-5 year after felling) and lack of proper substrata (the burning of felling waste in the community IIb). Most of epixylic species (Stereodon pallescens, Sciuro-hypnum reflexum, Callicladium haldanianum, etc.) are the colonists and are able to settle new substrata very fast. The composition of epixylic bryophytes in natural pine forests and secondary birch forests are quite similar because most species grow on the decaying wood and bases of birch trunks. Such substrates are common in both forest types.

The boreal forest floor species react to clear-cutting in different ways. Pleurozium schreberi turned to be more resilient to the disturbances due to high ecological amplitude and high rates of vegetative spread (Frego, 1996). Also, Hylocomium splendens was more resistant against changes in ecological regimes of habitats, which largely corresponds to the data from other regions (Hylander \& Johnson, 2010; Økland 1995). Ptilium crista-castrensis, Dicranum polysetum and Rhytidiadelphus triquetrus are almost absent in communities IIb and IIIa characterized by tall and thick herbaceous layer and long period of shading continuing for many years.

The colonists (Ceratodon purpureus, Atrichum undulatum, Dicranella heteromalla, Bryum caespiticium, Leptobryum pyriforme, Funaria hygrometrica, etc.) are particularly abundant during the period 5-10 years after felling and have reduced the frequency when young birch trees reached height 3-6 m and shaded the forest floor. Most of these species readily produce sporophytes and vegetative diaspores, which provide these plants with a rapid means of dissemination (Schimmel \& Granström, 1996). Some of these species dominate the communities on burned wood and scorched soil in boreal mixedwood forests of Canada and are considered to be disturbance 
(including post-fire) specialists (Ceratodon purpureus, Funaria hygrometrica, Leptobryum pyriforme) and ubiquitous (Pohlia nutans, Polytrichum juniperinum) (Bradbury, 2006). In contrast to study of Bradbury (2006), these species were not abundant in community IIb which formed after summer felling with burning waste, despite the availability of similar substrates. Probably, it can be explained by to shading effect of Chamaenerion angustifolium cover (80-100\%).

In the Southern Urals, the boreal pine forests are impacted by periodic natural disturbances, especially by creeping fires that are key factor providing for the maintenance of this forest type (Martynenko, 2002). Thus, bryophyte component of pine forests is adapted to the disturbances and, on the one hand, includes species with high ability to dissemination, on the other, is characterized by low presence of rare species that are most vulnerable to disturbances. For instance, the rare species represented $9 \%$ of bryophyte richness in dark coniferous forests and only $1 \%$ in pine and larch forests in Bashkortostan (Baisheva, 2010). The clear-cutting has severe negative effects on the survival possibilities for many rare and threatened species (Rudolphi et al., 2014). The low presence of rare species in the natural pine forests and a small number of investigated sample plots made it difficult to conduct the assessment of this phenomenon in our study. Some rare species of natural pine forests were not found in the secondary birch forests (Mnium spinosum, Cephaloziella hampeana, Lophocolea minor, etc.). It's difficult to say whether general patterns could be identified on the base of available observational data. Moreover most bryophytes typical for Urals natural pine forests are adapted to high solar radiation and have high abundance in such communities as mountain tundra (Pleurozium schreberi, Hylocomium splendens, etc.) or open woodlands (Dicranum montanum, Stereodon pallescens, Sciuro-hypnum reflexum, Ptilidium pulcherrimum, etc.). Consequently, the intense canopy openness in felled area is not a critical factor for surviving of these species. In the investigated secondary pine-birch forests, the bryophyte richness was almost recovered. However, the changes in species frequency and reduction of bryophyte cover were significant. The shift in secondary forests was primarily in reduction in abundance of individual species with elimination of few species with low frequency.

\section{ACKNOWLEDGEMENTS}

Authors are grateful to A. Kunafin for the collections provided for the studies and the assistance in the field work. Study was supported by RFBR, projects 13-0401410 and 13-04-01025.

\section{LITERATURE CITED}

[ALEKSANDROVA, V.D.] АЛЕКСАНДРОВА В.Д. 1964. Изучение смен растительного покрова. - [Study of successions] В кн.: Полевая геоботаника. T. 3 (ред. Лавренко E.M, A.A. Корчагин) [In: Lavrenko, E.M. \& A.A. Korchagin (eds.). Polevaya geobotanika. V.3] M.:Л., Наука [Moscow:Leningrad Nauka]: 300-447.
[ANDREYEV, G.V.] АНДРЕЕВ Г.В. 2011. Структура и динамика устойчиво-производных березняков западного макросклона на Южном Урале. - [Structure and dynamics of stable-secondary birch forests of western macro-slope in the Southern Urals] Вестник Алтайского государственного аграрного университета [Vestnik Altayskogo gosudarstvennogo agrarnogo universiteta] 11 (85): 39-43.

[BAISHEVA, E.Z.] БАИШЕВА Э.3. 2010. Эколого-фитоценотическая структура бриокомпонента лесной растительности Республики Башкортостан. - [Ecological-phytocoenotical pattern of bryophyte component of the forest vegetation in the Republic of Bashkortostan] Дисс....д-ра биол. наук. Уфа, Башгосуниверситет [PhD thesis, Ufa, Bashkir State University], 320 pp

[BAISHEVA, E.Z. \& P.S. SHIROKIKН] БАИШЕВА Э.3., П.С. ШИРОКИХ. 2014. О бриокомпоненте темнохвойных лесов Южного Урала. - [On the bryophyte flora of the dark coniferous forests in the Southern Urals] Известия Самарского научного иентра РАН [Izvestia Samarskogo nauchnogo tsentra RAN] 16 (5): 105-112.

[BAISHEVA, E.Z.] БАИШЕВА Э.3. 2012. О флоре мохообразных мезофитных широколиственных лесов Южного Урала. - [On the bryophyte flora of the mesophytic broad-leaved forests in the Southern Urals Mts.] Известия Самарского научного иентра PAH [Izvestia Samarskogo nauchnogo tsentra RAN] 14 (1/7): 1689-1692.

[BAISHEVA, E.Z.] БАИШЕВА Э.3. 2013. К флоре мохообразных темнохвойно-широколиственных лесов Южного Урала. - [То the bryophyte flora of the dark coniferous-broadleaved forests in the Southern Urals Mts.] Известия Самарского научного иентра РАН [Izvestia Samarskogo nauchnogo tsentra RAN] 15 (3/4): 1210-1214.

BRADBURY, S.M. 2006. Response of the post-fire bryophyte community to salvage logging in boreal mixedwood forests of northeastern Alberta, Canada. - Forest Ecology and Management 234: 313-322.

BRAUN-BLANQUET, J. 1964. Pflanzensoziologie. Grundzuge der Vegetationskunde. - Wien-New York, Springer-Verlag, 865 pp.

[CHEREPANOV, S. K.] ЧЕРЕПАНОВ С.К. 1995. Сосудистые растения России и сопредельных государств. - [Vascular plants of Russia and adjacent countries]. Санкт-Петербург, Мир и семья [Sankt-Petersburg, Mir i sem'ya], $990 \mathrm{pp}$.

FOSTER, B. L. \& D. TILMAN. 2000. Dynamic and static views of succession: Testing the descriptive power of the chronosequence approach. - Plant Ecology 146: 1-10.

FREGO, K. 1996. Regeneration of four boreal bryophytes: colonization of experimental gaps by naturally occurring propagules. - Canadian Journal of Botany 74: 1937-1942.

HENNEKENS, S.M. \& J.H.J. SCHAMINÉE. 2001. TURBOVEG, a comprehensive data base management system for vegetation data. - Journal of Vegetation Science 12: 589-591.

HYLANDER, K. \& S. JOHNSON. 2010. In situ survival of forest bryophytes in small-scale refugia after an intense forest fire. - Journal of Vegetation Science 21: 1099-1109.

IGNATOV, M.S., O.M. AFONINA, E.A. IGNATOVA et al. 2006. Check-list of mosses of East Europe and North Asia. - Arctoa 15: 1-130.

IVANOVA, N. 2014. Differentiation of forest vegetation after clear-cuttings in the Ural Montains. - Modern Applied Science 8 (6). http:// dx.doi.org/10.5539/mas.v8n6p195.

IVANOVA, N.S. \& E.S. ZOLOTOVA. 2014. Development of Forest Typology in Russia. - International Journal of Bio-resource and Stress Management. 5(2): 298-303.

JALONEN, J. \& I. VANHA-MAJAMAA. 2001. Immediate effects of four different felling methods on mature boreal spruce forest understory vegetation in southern Finland. - Forest Ecology and Management 146: 25-34.

[KHAIRETDINOV, A.F. (ed.)] ХАЙРЕТДИНОВ А.Ф. (ред.). 2004. Леса Башкортостана. - [Forests of Bashkortostan] Уфa, БГАУ [Ufa, $B G A U$ ], $400 \mathrm{pp}$.

[KOLESNIKOV, B.P.] КОЛЕСНИКОВ Б.П. 1974. Генетический этап в лесной типологии и его задачи. - [Genetic state of the forest typology and its tasks] Лесоведение [Lesovedenie] 2: 3-20 
KONSTANTINOVA, N.A., V.A. BAKALIN et al. 2009. Checklist of liverworts (Marchantiophyta) of Russia. - Arctoa 18: 1-64.

[KORCHAGIN, A.A.] КОРЧАГИН А.А. 1960. Определение возраста деревьев умеренных широт. - [Determination of tree age at temperate latitudes]. В кн.: Полевая геоботаника. T. 2. (ред. Лавренко Е.M., A.A. Корчагин) [In: Lavrenko, E.M. \& A.A. Korchagin (eds.). Polevaya geobotanika. V.2.] М.: Л., Изд. АН СССР [Moscow \& Leningrad, Izdatel'stvo AN SSSR]: 209-240.

[KOROTKOV, K.O. \& O.V. MOROZOVA] KOРOTKOB K.O., O.B. МОРОЗОВА. 1989. Бриофлора Валдайского лесничества (Новгородская область). - [The bryophyte flora of Valday Forestry] Ботанический Журнал [Botanicheskij Zhurnal] 74 (3): 395-405.

[KUNAFIN, A.M.] КУНАФИН А.М. 2014. Синтаксономический анализ динамики вырубок и вторичных лесов центрально-возвышенной части Южного Урала. - [Syntaxonomic analysis of vegetation dynamic in the cutover areas and secondary forests in the central part of the Southern Urals] Дисс. ...канд. биол. наук. Уфа, Башгосуниверситет $[P h D$ thesis, Ufa, Bashkir State University], 219 pp.

MARSCHALL, M. \& M.C.F. PROCTOR. 2004. Are bryophytes shade plants? Photosynthetic light responses and proportions of Chlorophyll a, Chlorophyll b and total carotenoids. - Annals of Botany 94: 593-603.

MARTYNENKO, V. B. 2002. Ground fires as a factor of maintenance of pine-larch forests in the Southern Urals. - Russian Journal of Ecology 33 (3): 212-215.

[MARTYNENKO, V.B.] МАРТЫНЕНКО, В.Б. 2009. Синтаксономия лесов Южного Урала как теоретическая основа развития системы их охраны. - [Syntaxonomy of Southern Urals forests vegetation as the basis for development of forests protection system] Дисс....д-pa биол. наук. Уфа, Башгосуниверситет [PhD thesis, Ufa, Bashkir State University], $495 \mathrm{pp}$.

[MULDASHEV, A.A. (ed.)] МУЛДАШЕВ, А.А. (ред.). 2010. Реестр особо охраняемых природных территорий Республики Башкортостан. Изд. 2-e. - [Registry of nature protected areas of Republic of Bashkortostan. $2^{\text {nd }}$ ed.] У

ØKLAND, R.H. 1995. Population biology of the clonal moss Hylocomium splendens in Norwegian boreal spruce forests. 1. Demography. Journal of Ecology 83: 697-712.
RAMBO, T. R. 2001. Decaying logs and habitat heterogeneity: Implications for bryophyte diversity in western Oregon forests. - Northwest Science 75: 270-279.

RUDOLPHI, J. \& L. GUSTAFSSON. 2011. Forests regenerating after clear-cutting function as habitat for bryophyte and lichen species of conservation concern. - PLoS One 6(4): e18639. doi: 10.1371/ journal.pone.0018639.

RUDOLPHI, J., M.T. JÖHNSSON \& L. GUSTAFSSON. 2014. Biological legacies buffer local species extinction after logging. - Journal of Applied Ecology 51: 53-62.

SCHMALHOLZ, M. \& K. HYLANDER. 2009. Succession of bryophyte assemblages following clear-cut logging in boreal spruce-dominated forests in south-central Sweden - does retrogressive succession occur? - Canadian Journal of Forest Research 39(10): 1871-1880.

SCHIMMEL, J. \& A. GRANSTRÖM. 1996. Fire severity and vegetation response in the boreal Swedish forest. - Ecology 77: 1436-1450.

SHIROKIKH, P.S., V.B. MARTYNENKO \& A.M. KUNAFIN. 2013. Experience in syntaxonomic and ordination analysis of progressive succession in cutover areas of boreal light conifer forests in the Southern Urals. - Russian Journal of Ecology 44(3): 185-192.

TICHÝ, L., J. HOLT \& M. NEJEZCHLEBOVÁ. 2011. JUICE. Program for management, analysis and classification of ecological data. $2^{\text {nd }}$ ed. Brno, Masaryk university, $61 \mathrm{pp}$.

VAN ZANTEN, B.O. \& T. PÓCS. 1981. Distribution and dispersal of bryophytes. - Advances of Bryology 1: 479-562.

YAN, X. L., W. K. BAO, X.Y. PANG, N.X. ZHANG \& J. CHEN. 2013. Regeneration strategies influence ground bryophyte composition and diversity after forest clearcutting. - Annals of Forest Science 70 (6). DOI 10.1007/s13595-013-0323-7.

[YAPAROV, I. (ed.)] ЯПАРОВ И. (ред.). 2005. Атлас республики Башкортостан. - [Atlas of the Republic of Bashkortostan] - У $\phi a$, ГУП ГРИ «Баикортостан» [Ufa, GUP GRI “Bashkortostan”], $420 \mathrm{pp}$.

[ZVEREV, А.А.] 3ВEPEB, А. А. 2007. Информационные технологии в исследованиях растительного покрова. - [Information technologies in the plant cover investigations]. Томск: ТМЛ-Пресс [Tomsk: TML-Press], $304 \mathrm{pp}$. 